Discussion Paper No. 09-045

The European Commission and EUA Prices:

A High-Frequency Analysis of the EC's Decisions on Second NAPs

Waldemar Rotfuß, Christian Conrad, and Daniel Rittler

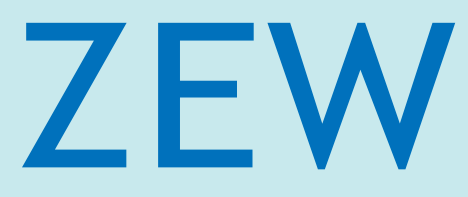

Zentrum für Europäische Wirtschaftsforschung $\mathrm{GmbH}$ Centre for European Economic Research 
Discussion Paper No. 09-045

\title{
The European Commission and EUA Prices: \\ A High-Frequency Analysis of the EC's Decisions on Second NAPs
}

\author{
Waldemar Rotfuß, Christian Conrad, \\ and Daniel Rittler
}

Download this ZEW Discussion Paper from our ftp server:

ftp://ftp.zew.de/pub/zew-docs/dp/dp09045.pdf

Die Discussion Papers dienen einer möglichst schnellen Verbreitung von neueren Forschungsarbeiten des ZEW. Die Beiträge liegen in alleiniger Verantwortung der Autoren und stellen nicht notwendigerweise die Meinung des ZEW dar.

Discussion Papers are intended to make results of ZEW research promptly available to other economists in order to encourage discussion and suggestions for revisions. The authors are solely responsible for the contents which do not necessarily represent the opinion of the ZEW. 


\section{Non-technical Summary}

This paper investigates price formation in the European Union Emissions Trading Scheme (EU ETS). The aim of the paper is to know what is happening to the European Union Allowance (EUA) price, when new information hits the EU ETS. The focus lies on EUA prices reactions to the European Commission's decisions (the EC's decisions) on second National Allocation Plans (NAPs). Since prices should react only to unexpected information, a model of expectation-formation is provided, where agents anticipate the EC's decision on second NAPs. An empirical analysis supports the model; unexpected allocations of emissions allowances leads to pronounced price reactions of the expected signs. Moreover, the adjustment is not instantaneous, but takes up to six hours after the decision announcement.

The obtained results allow following conclusions. Our regression model is able to explain the EUA price reactions immediately after the publication of the EC's decision on second NAPs. In particular, EUA prices adjust in the expected direction as a simple economic model of supply and demand would suggest. Hence, there is no evidence that EUA prices are disconnected from the considered fundamental factor, namely the overall supply of EUAs in the second commitment period. However, the slow adjustment of EUA prices to new information suggests that the EU ETS is not fully informationally efficient regarding the determination of the size of the overall cap. 


\section{Das Wichtigste in Kürze}

In dieser Arbeit wird die Preisbildung im europäischen Emissionshandel (EU ETS) untersucht. Der Schwerpunkt der Untersuchung liegt auf Preisreaktionen von $\mathrm{CO}_{2}$ Zertifikaten, die unmittelbar nach Veröffentlichung der Entscheidung der Europäischen Kommission (EC) über die Höhe der zweiten Nationalen Allokationspläne (NAPs) erfolgen. Da Preise nur auf unerwartete Informationen reagieren sollten, wird ein Erwartungsbildungsmodell spezifiziert, in dem Agenten die Entscheidung der EC über die Höhe der zweiten Nationalen Allokationspläne prognostizieren. Eine empirische Überprüfung bestätigt das Modell - unerwartete Zuteilung von Emissionsberechtigungen führt zu ausgeprägten Preisreaktionen mit entsprechenden Vorzeichen. Zudem scheint die Anpassung der Preise auf neue Informationen langsam zu erfolgen. Auf der Basis einfacher Querschnittsregressionen dauert die Anpassung bis zu sechs Stunden.

Die erzielten Ergebnisse erlauben folgende Schlussfolgerungen: Unser Regressionsmodel ist fähig die Preisreaktionen zu erfassen, die unmittelbar nach der Entscheidung der EC über die Höhe der zweiten NAPs stattfinden. Die Preise passen sich in die richtige Richtung an, so wie ein einfaches ökonomisches Model für Angebot und Nachfrage es nahelegt. Es gibt daher keine Anhaltspunkte für eine Loslösung der Preise von dem betrachteten fundamentalen Faktor, nämlich der Festsetzung des gesamten Angebots an Emissionsberechtigungen in der zweiten Verpflichtungsperiode. Die langsame Preisanpassung deutet allerdings darauf hin, dass die Preisbildung im EU ETS nicht vollständig informationseffizient hinsichtlich des betrachteten Faktors ist. 


\title{
The European Commission and EUA Prices: A High- Frequency Analysis of the EC's Decisions on Second NAPs
}

\author{
Waldemar Rotfuß ${ }^{*}$, Christian Conrad ${ }^{\dagger}$, Daniel Rittler ${ }^{\ddagger}$
}

September 2009

\begin{abstract}
This paper empirically examines price formation in the European Union Emissions Trading Scheme (EU ETS). Our analysis shows that unexpected allocations of European Union Allowances (EUAs) lead to pronounced price reactions of the expected signs. Moreover, we find evidence that the adjustment of EUA prices to the European Commission's decisions on second National Allocation Plans (NAPs) is not instantaneous, but takes up to six hours after the decision announcement.
\end{abstract}

Keywords: EU ETS, Price Formation, European Union Allowance (EUA), European Commission JEL Classification: G13, G14, G15, G17, G19, Q4, Q5

\footnotetext{
* Waldemar Rotfuß (Corresponding author), Centre for European Economic Research (ZEW), Mannheim, P.O. Box 1034 43, 68034 Mannheim, Germany, E-mail: rotfuss@zew.de; Phone: +49/621/1235/141, fax: $+49 / 621 / 1235223$.

${ }^{\dagger}$ Christian Conrad, Department of Economics, University of Heidelberg, Bergheimer Straße 58, 69115 Heidelberg, Germany, E-Mail: christian.conrad@awi.uni-heidelberg.de; Phone: +49/6221/54/3173.

${ }^{\ddagger}$ Daniel Rittler, Department of Economics, University of Heidelberg, Bergheimer Straße 20, 69115 Heidelberg, Germany, E-Mail: daniel.rittler@awi.uni-heidelberg.de; Phone: +49/6221/54/2926.
} 


\section{Introduction}

As yet, little is known about the price formation in the European Union Emissions Trading Scheme (EU ETS). For example, it is not known whether the European Union Allowance (EUA) prices fully and correctly reflect all publicly available information. In this paper we employ the European Commission's decisions (EC's decisions) on second National Allocation Plans (NAPs) to analyse the EUA price reactions to new information. Related studies such as Mansanet-Bataller et al. (2007), Mansanet-Bataller and Pardo (2007), Alberola et al. (2008) and Chevallier (2009) provide first empirical evidence on the relation between fundamentals and price formation in the EU ETS. However, they do not focus on the impact of new information. This paper explicitly employs market expectations and high-frequency data and, therefore, is able to reveal novel aspects of price formation in the EU ETS.

\section{Model of Expectation-formation}

The EC's decisions on NAPs play a key role in the determination of the size of the overall cap in the EU ETS (for details, see European Parliament and Council, 2003). In order to investigate the impact of the EC's decisions on EUA prices we have to account for the expected component of each decision, since only unexpected information should affect prices. Our model of expectation-formation uses two facts about the approval of second NAPs. First, according to our investigation of the EU ETS framework, the study of related press releases, and interviews with market participants, it is widely accepted among market participants to treat the first NAPs as a point of reference for the second NAPs. Second, previous the first decision announcement, it was clear to all market participants that the EC will allow only tight caps in the second commitment period (for details, see e.g. Barosso, 2006a,b). Hence, for each member state $i=1,2, \ldots, 27$, we model the conditional market expectations with respect to the EC's decision on the total number of EUAs in the second NAP, $E\left[y_{i} \mid F_{i-}\right]$, as a function of $X_{i}$, the total number of EUAs in the first NAP,

$$
E\left[y_{i} \mid F_{i-}\right]= \begin{cases}(1-\text { cut }) \cdot X_{i} & \text { if } y_{i}^{\text {submitted }}>(1-\text { cut }) \cdot X_{i} \\ y_{i}^{\text {submitted }} & \text { if } y_{i}^{\text {submitted }} \leq(1-\text { cut }) \cdot X_{i},\end{cases}
$$

where cut is a real constant between 0 and 1 . cut can be considered as a lump cut from the first NAPs. $y_{i}^{\text {submitted }}$ is the total number of EUAs in the second NAP of the member state $i$ that has been submitted to the EC for approval. $y_{i}$ represents the total number of EUAs in the second NAP that has been approved by the EC. $F_{i-}$ is the information set of all market participants before the considered decision that includes $X_{i}$ and $y_{i}^{\text {submitted }}$, but not $y_{i}$. The conditional expectation is equal to the submitted number of EUAs, if cut leads to a greater or an equal number than submitted to the EC (our escape clause). ${ }^{1}$

\footnotetext{
${ }^{1}$ Our escape clause assures rational expectations of market participants. It has to be included into the model, because of the strong aim of the EC to tighten the national totals in the second commitment period and the fact that member states have an incentive to be generous with their allocation.
} 
In order to test for which values of cut our model delivers unbiased expectations, we regress $y_{i}$ on the above expectations for several choices of cut $(0.00,0.025,0.05,0.075,0.10)$. The results indicate no expectation bias. In particular, the estimated intercept is not statistically significantly different from zero in all regressions. The estimated slope coefficient is close to and not significantly different from one. The coefficient of determination is in all cases above 0.995. A joint test of the null that the intercept is zero and the slope is one cannot be rejected at the usual significance levels in all regressions. Thus, the stated expectation-formation leads to no systematic deviations from the realized values for reasonable values of cut. We report results for cut equal 7.5 per cent. This choice is justified by the calculations presented later in the paper. However, the results are qualitatively similar for other values of cut.

\section{Data and Methodology}

\subsection{Price and Announcement Data}

We use price data for the ICE ECX EUA December 2008 futures contract, which is the most liquid futures contract in the period of interest. The high-frequency price data are obtained from the ICE Futures/European Carbon Exchange (ECX), the leading exchange for trading in EUA futures. After correcting for outliers, we calculate equidistant prices for each 10-minute interval during the trading session as the mean of the preceding and immediately following transaction prices. A detailed description of the data is available in Rotfuß (2009). ${ }^{2}$

The announcement data, especially the number of approved EUAs in the first and second NAPs, are gathered from the EC's website and the relevant press releases. The publication time of the EC's decisions is taken from Point Carbon, a well-known news agency among EU ETS participants. In several cases the EC approved the second NAPs on the condition that changes are made to the total number of emission allowances. In a few cases the EC proposed informal emission caps, which the member states either accepted or dismissed by withdrawal of the proposed NAP shortly before the decision. There are in total 36 announcements on second NAPs: 27 (conditional) approvals, six decisions on amended and resubmitted NAPs, and three information leakages - publications of the EC's decisions before the announcement of the actual decision. We focus only on the 27 (conditional) approvals that were made in the period from 11/29/2006 to $10 / 26 / 2007$, but account for the information leakages (relevant in the case of Germany and Belgium) to avoid measurement errors arising from stale information. $^{3}$ We account for the information leakages by replacing the calculated expectations for Germany and Belgium with the leaked out values. Due to low liquidity at the beginning of the considered announcement period and the rapid succession of the announcements on four days, it is not possible to measure the effect of each announcement

\footnotetext{
${ }^{2}$ The average EUA price in the period of interest (11/29/2006 - 10/26/2007) equals 19.92 Euro.

${ }^{3}$ The announcement data can be provided by the authors upon request. Note that 27 decisions were made on 14 days. Ten of these decisions were made on a single day. There are also two days each with two decisions and one day with three decisions. The remaining ten announcements were made on separate days.
} 
separately. Instead, 17 announcements that occurred on four trading days are summarized into four (compiled) announcements to have only one announcement per trading day. The calculation of the relevant quantities occurs in a straightforward fashion; the time stamps of the first announcements on the four trading days are assigned to the four compiled announcements. The other quantities are defined as the sum of their respective individual counterparts. After doing so, we are left with 14 announcements that we employ in our regressions.

\subsection{Methodology}

We use simple cross-sectional methods similar to Almeida et al. (1998) to assess the EC's decisions on second NAPs on the EUA prices. If the proposed expectation-formation in Section 2 is correct, then the surprise component should be able to explain the price changes immediately after the announcements. The central equation that we use in our empirical analysis is given by the following formula,

$$
r_{t_{i}+\Delta t}=\alpha+\beta \cdot S_{i}+\varepsilon_{t_{i}+\Delta t}
$$

where $r_{t_{i}+\Delta t}$ is defined as the difference of two EUA prices, $p_{t_{i}+\Delta t}-p_{t_{i}}{ }^{4} t_{i}$ represents the first equidistant 10-minute interval after the considered announcement $i$ has reached the market. $\Delta t$ is defined as the elapsed time after $t_{i}$ measured in minutes and $\varepsilon_{t_{i}+\Delta t}$ is the appropriate error term. The surprise component $S_{i}$ is defined as $S_{i}=E\left[y_{i} \mid F_{i-}\right]-y_{i}$, which is simply the difference between the expected and the approved number of EUAs in the second NAP of the member state $i$. The standard deviation of $S_{i}$ equals almost 6 million EUAs, the maximum and minimum values are 12.7 and -19.3 million EUAs, respectively. A positive (negative) $S_{i}$ implies an unexpected cut (over-allocation) of the national total. The investigation of price reactions is performed for several values of $\Delta t$. In particular, in the first step we fix $\Delta t$ at the time period between the announcement instant and the closure of the trading session (what leads to $\Delta t_{i}=T-t_{i}$, where $T$ equals the point in time of the trading session closure) ${ }^{5}$, and in the second step at $10,20, \ldots, 480$ minutes.

If the model of expectation-formation is sufficiently accurate, the estimate of $\beta$ should be positive and significant, since a positive surprise implies a reduction of supply of EUAs. The estimate of $\alpha$, on the other hand, should be small and statistically not different from zero, since only surprises should contain new information.

\section{Empirical Results}

\footnotetext{
4 All results are robust to the use of logarithmic price changes rather than absolute price changes as the dependent variable.

${ }^{5}$ The average time between the announcement instant and the closure of the trading session equals 361 minutes.
} 
The empirical results are presented in Table 1 und Figure 1. In particular, unexpected cuts lead to price increases and unexpected over-allocation to price decreases. An unexpected cut of 1 million EUAs leads to an EUA price increase of 4.6 Euro cents when we consider price changes between the announcement instant and the closure of the trading session $\left(\Delta t_{i}=T-t_{i}\right)$, see Table 1. The effect is significant given its $t$-value of 5.3. The 95 per cent confidence interval of the impact ranges from 2.7 to 6.4 Euro cents. The estimated constant equals 1 Euro cent, which we consider to be not statistically different from zero due to its significance level of almost 15 per cent. Finally, our model seems to explain the variation of considered EUA price changes fairly well - the coefficient of determination equals 70 per cent.

Turning the focus to time periods up to 480 minutes after the announcement instant reveals a graduate adjustment of the EUA prices to new information. As the estimate of $\beta$ in the upper part of Figure 1 suggests, an unexpected cut of 1 million EUAs leads to a price increase of 2 Euro cents within 60 minutes after the announcement instant. Moreover, the impact is not only positive, but also statistically significant. Of course, this price adjustment is not necessarily slow for a new market. However, further estimation results for longer time periods reveal an adjustment within six hours: Beginning at 160 minutes after the announcement instant, the price adjustment increases from 2 Euro cents, within 190 minutes to 4.9 Euro cents. Shortly thereafter, the impact of the surprises becomes insignificant, but remains at the same level. For the same time intervals up to eight hours after the announcements instant, the estimate of $\alpha$ is small and, what is more important, in most cases not statistically different from zero (see lower part of Figure 1).

If we assume that market participants are to some extent not rational and drop our escape clause in the stated expectation-formation model, then we are able to estimate cut by simply regressing $y_{i}$ on $X_{i}$. In this case, the estimated slope coefficient equals 1-cut and the residuals can be regarded as surprises or forecasting errors. The obtained estimate of 1-cut equals 0.919 and is statistically different from one, suggesting a value of 8.1 per cent for cut, which is not that far from the value of 7.5 per cent. The estimate is significant at all reasonable levels and its 95 per cent confidence interval spans the set of real numbers from 0.900 to 0.939 . The estimated impact of calculated forecasting errors on the EUA price changes amounts to 3.3 Euro cents and is also significant. The appropriate 95 per cent confidence interval includes all real values from 1.5 to 5.0 Euro cents.

The overall pattern of the estimated impact does not change when we consider other values of cut between 0 and 10 per cent. In most cases, the estimated impact of the surprises is positive and significant and exhibits a gradual increase. Again, the random fluctuations of EUA prices do not become evident until six hours after the announcement instant. The significance is smaller in most cases for the more extreme choices of cut. The estimated intercept is small and insignificant in most regressions when measuring price changes over intervals up to eight 
hours. Therefore, the results seem to be robust across different post-announcement intervals and reasonable lump cut values.

\section{Conclusions}

Based on our results we can draw the following conclusions. Our regression model is able to explain the EUA price reactions immediately after the publication of the EC's decision on second NAPs. In particular, EUA prices adjust in the expected direction as a simple economic model of supply and demand would suggest. Hence, and contrary to Mansanet-Bataller and Pardo (2007), there is no evidence that EUA prices are disconnected from the considered fundamental factor, namely the overall supply of EUAs in the second commitment period. However, the slow adjustment of EUA prices to new information suggests that the EU ETS is not fully informationally efficient regarding the determination of the size of the overall cap. Several open questions remain for further research. First of all, the investigation of the relation between other fundamentals and EUA prices at high-frequency, e.g. oil, coal, gas, or electricity prices, deserves a thorough analysis. Another question is the reason for the slow adjustment of EUA prices to new information. It might be that the slow adjustment to new information is simply one of the teething problems of the EU ETS. It might be, however, that the structure of the EU ETS produces impediments to adjustment.

\section{Acknowledgements}

This paper has benefited from comments by Jürgen Kähler and Francois Laisney. We thank Qingwei Wang, Christian D. Dick, Svitlana Voronkova, and participants at the ZEW MacroFinance Seminar for their numerous suggestions. We thank also Carl J. Ullrich and other participants at the 36th Annual EFA Meeting (2009, Bergen) for their valuable comments and suggestions. One anonymous reviewer of the first version of this paper provided important suggestions for further research.

\section{References}

Alberola, E., J. Chevallier, and B. Chèze, 2008, Price Drivers and Structural Breaks in European Carbon Prices 2005 - 2007, Energy Policy, 36 (2), 787-797.

Almeida, A., C. Goodhart, and R. Payne, 1998, The Effects of Macroeconomic News on High Frequency Exchange Rate Behavior, Journal of Financial and Quantitative Analysis 33 (3), 383-408.

Barroso, J.M., 2006a, Changement Climatique et Énergie: La Détermination De L’Europe, La Tribune, 21.11.2006.

Barroso, J.M., 2006b, The Scottish Enlightenment and the Challenges for Europe in the 21st

Century; Climate Changes and Energy, Enlightenment Lectures Series, Edinburgh University, 28.11.2006.

Chevallier, J., 2009, Carbon Futures and Macroeconomic Risk Factors: A View From the EU ETS, Energy Economics, 31 (4), 614-625.

European Parliament and Council, 2003, Directive 2003/87/EC of the Eruopean Parliament and of the Council of 13 October 2003. Official Journal of the European Union L 275, 32-46.

Mansanet-Bataller, M. and T. Pardo, 2007, The Effects of National Allocation Plans on Carbon-Markets, Working Paper, Faculty of Economics, University of Valencia. 
Mansanet-Bataller, M., A. Pardo, and E. Valor, 2007, $\mathrm{CO}_{2}$ Prices, Energy and Weather, The Energy Journal, 28 (3), 67-86.

Rotfuß, W., 2009, Intraday Price Formation and Volatility in the European Union Emissions Trading Scheme: An Introductory Analysis, ZEW Discussion Paper 09-018, Mannheim.

\section{Appendix}

Table 1: The impact of the EC's decisions on EUA price changes measured over a fixed period

\begin{tabular}{|c|c|c|c|c|c|c|}
\hline \multicolumn{7}{|c|}{ Dependent variable: EUA price changes } \\
\hline & Coef. & Std. Error & $\mathrm{t}$ & $\mathrm{P}>|\mathrm{t}|$ & \multicolumn{2}{c|}{$95 \%$ Confidence-Interval } \\
\hline$\alpha$ & -0.099 & 0.064 & -1.550 & 0.147 & -0.239 & 0.040 \\
\hline$\beta$ & 0.046 & 0.009 & 5.320 & 0.000 & 0.027 & 0.064 \\
\hline \multicolumn{6}{|c|}{ Overall-F-Test } & \multicolumn{2}{c|}{ Coefficient of determination } & Number of observations \\
\hline $\mathrm{F}(1,12)=28.33$; Prob > F = 0.0002 & \multicolumn{3}{|c|}{$\mathrm{R}^{2}=0.70$} & \multicolumn{2}{c|}{ Nobs $=14$} \\
\hline
\end{tabular}

The dependent variable is the EUA price change between the announcement instant and the closing of the trading session; the independent variable is the unexpected information $S_{i}$ (for definition, see Section 3.2). The value of cut equals $7.5 \%$.

Figure 1: The impact of the EC's decisions on EUA price changes measured over several periods
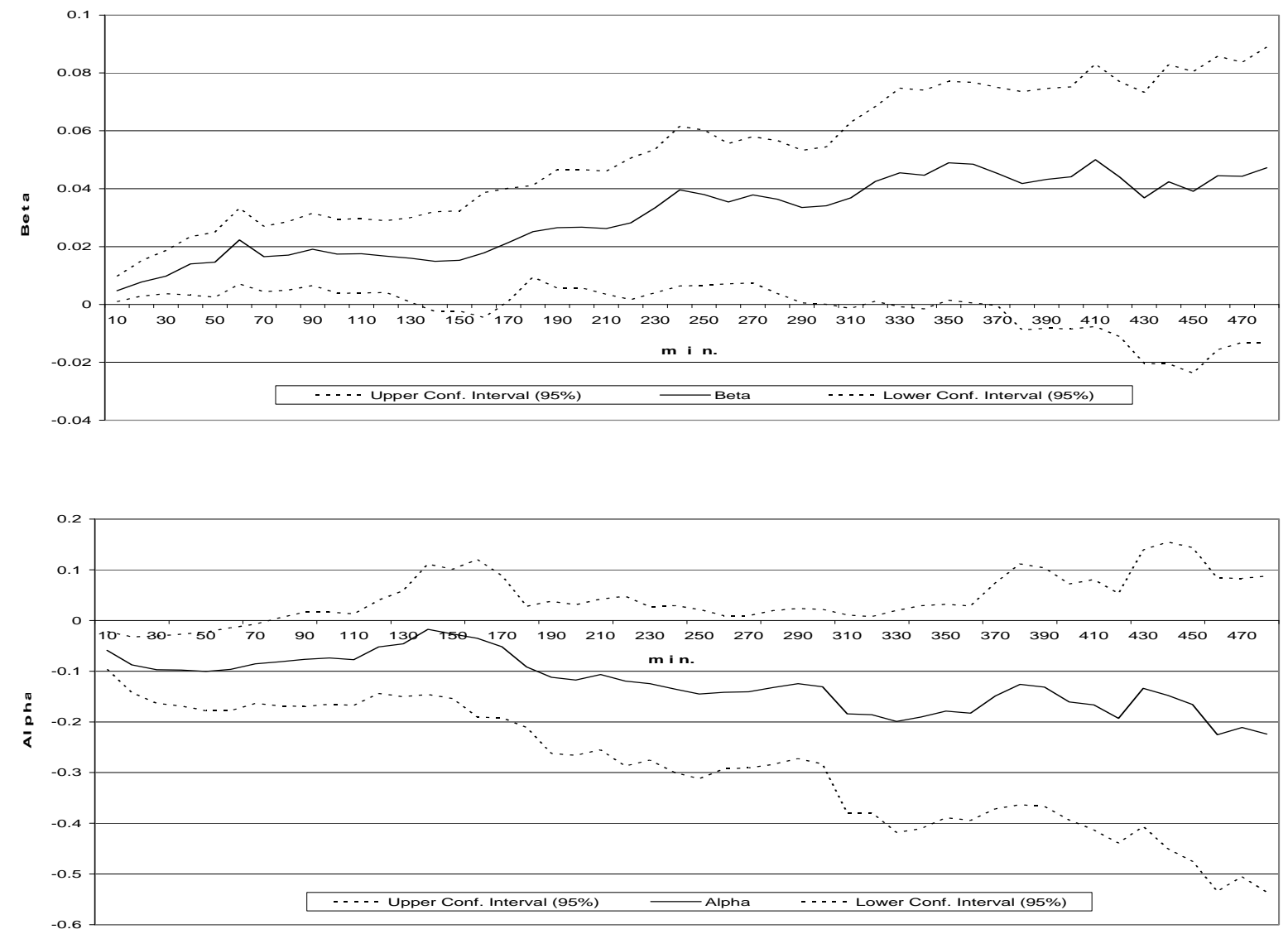

The figure presents the estimates of $\beta$ (upper) and $\alpha$ (lower), both indicated by the solid line, and their corresponding 95 per cent confidence intervals (dotted lines) from the regression of EUA price changes over several time periods (indicated by the x-axis) on the unexpected information $S_{i}$ (for more details, see Section 3.2). The time intervals are measured in minutes after the announcement instant. The value of cut equals $7.5 \%$. 